\title{
The Spreading Of Spodoptera litura Multiple Nucleopolyhedrosis Virus in Midgut of Third Instar of Spodoptera Litura Larvae
}

\author{
Mahanani Tri Asri ${ }^{1,2}$, Siti Rasminah Ch. Sy ${ }^{1}$, Bambang Tri Rahardjo ${ }^{3}$, \\ Sutiman B. Sumitro ${ }^{4}$ \\ ${ }^{I}$ Department of Biology, Faculty of Mathematics and Natural Sciences, State University of Surabaya, Jl. \\ Ketintang Surabaya, Indonesia \\ ${ }^{2}$ Doctoral Program, Faculty of Agriculture, Brawijaya University, Indonesia \\ ${ }^{3}$ Plant Pests and Diseases, Faculty of Agriculture, Brawijaya University, Indonesia \\ ${ }^{4}$ Department of Biology, Faculty of Mathematics and Natural Sciences, Brawijaya University, Indonesia
}

\begin{abstract}
Analyses on the spreading of SpltMNPV (Spodoptera litura Multiple Nucleopolyhedrosis Virus) multiplied in midgut epithelium cell of in third instar of S. litura larvae has been done through histological studies. The aim of this study was to examine the distribution of SpltMNPV in S. litura larvae. The third instars of S. litura larvae that had been infected with SpltMNPV were incubated for 0, 24, 48, and 72 hours. Afterwards, the infected S. litura larvae were cut crosswise in the anterior, middle, and posterior of the midguts. The crosswise cuts at the midguts were fixed using Gilson solution, executed under the paraffin method, and cut as thick as of $4 \mu \mathrm{m}$, and then stained with Hematoxylin and eosin. The results of this study indicate that SpltMNPV (PIB, Polyhedral inclusion bodies) have infected various organs of the S. litura larvae, i.e. lumen, peritrophic membrane, midgut epithelial layers, trachea, blood vessels, malpigian tubules, muscle cells and adipocyte. The only organ which is not infected by SpltMNPV is the cuticle.
\end{abstract}

Keyword: SpltMNPV, midgut epithelial cells, and Spodoptera litura

\section{Introduction}

Spodopteralitura is often known as Tropical armyworm. This worm is an agricultural pest which is very harmful because its attack is simultaneous and in bulk (Kartohardjono and Arifin, 2000). S. litura attacks cause $12.5 \%$ to over $20 \%$ destruction in soybean plantation of over 20 days of age (Adisarwanto and Widianto, 1999). The damage can cause the loss of $85 \%$ of the yield, or even crop failure (Marwoto and Suharsono, 2008). One of the viruses being developed to control Spodoptera litura is SpltMNPV (Spodopteralitura Multiple Nucleo polyhdrosis Virus). According to Asri \& Isnawati (2005), SpltMNPV in $10^{6} \mathrm{PIBs} / \mathrm{ml}$ (Polyhedra inclusion bodies $/ \mathrm{ml}$ ) concentrations is effective to control $S$. litura as to increase mortality rate into $80-90 \%$ in a laboratory-based experiment and $10^{7} \mathrm{PIBs} / \mathrm{ml}$ in a greenhouse-based experiment (Asri, 2004).

The propagation of SpltMNPV is usually done using the S. litura worm. This method, however, faces many obstacles, i.e. the high rates of deaths of the larvae in the culturing process in laboratory. SpltMNPV cultured in an in vitro condition at the midgut epithelial cells of $S$. litura larvae is feasible (Asri and Nur, 2008). Usually SpltMNPV proliferates in epithelial cells or in their derivatives. Accordingly, this study examined the distribution of SpltMNPV in midgut of $S$. litura larvae.

\section{Materials and Methods}

Multiplication of SpltMNPV in epithelial cell culture

Multiplication of SpltMNPV in the epithelial cells of S. litura was done through an in vitro method. The SpltMNPV used in this study was isolated from S. litura larvae died infected by viruses in areas in Central Java, Indonesia (Wahyuni, 2002). The SpltMNPV was purified through a centrifugation method (Arifin, 1994), and the concentration was calculated using a Haemocytometer. Polyhedra of SpltMNPV $\left(1.1 \times 10^{6}\right.$ PIBs $\left./ \mathrm{ml}\right)$ was broken using $\mathrm{Na}_{2} \mathrm{CO}_{3} 0.5 \mathrm{M}$. The SpltMNPV without polyhedra was inoculated in midgut epithelial cell with a cell concentration of $7.6 \times 10^{7}$ cells $/ \mathrm{ml}$. The infected epithelial cells were grown in Grace's medium enriched with fetal bovine serum $2.5 \%$ and incubated at the temperature of $28-30^{\circ} \mathrm{C}$ in three days. The SpltMNPV in Grace's medium was harvested through a centrifugation method of $3500 \mathrm{rpm}$ for about 15 minutes. The number of SpltMNPV in Supernatant was counted using a Haemocytometer.

\section{Infection of SpltMNPV in S. litura larvae}

The amounts of SpltMNPV $\left(7.8 \times 10^{7} \mathrm{PIBs} / \mathrm{ml}\right)$ were used to infect 30 of S. litura larvae through a feeding contamination method (Asri, 2009). These 30 infected larvae were grouped into three group, ie. 10 larvae were incubated for 24 hours, another 10 larvae were incubated for 48 hours, and the rest 10 larvae were 
incubated for 72 hours. In addition, 10 larvae were used as control group (given no treatment of SpltMNPV). During the incubation, the infected $S$. litura larvae were fed with artificial food and incubated at room temperature $\left(28-30^{\circ} \mathrm{C}\right)$. The infected larvae were examined on morphological changes during the incubation.

\section{Histology preparation}

The histological preparation was done using a modified paraffin method (Thamrin, et.al, 2012). The infected larvae incubated for $0,24,48$, and 72 hours were fixed with Gilson solution. The larvae were cut crosswise at the anterior, middle, and posterior midgut. The midgut pieces were immersed in ethanol $70 \%$ for at least 24 hours. Dehydration was done in alcohol of 70\% titration (4 × 20 minutes), 80\% ( $2 \times 20$ minutes), 96\% ( 1 x 20 minutes) and absolute alcohol (1 x 20 minutes). Clearing process was done in eugenol for 24 hours. Then, the samples were soaked in paraffin until they were frozen and were through the processes of Embedding, Trimming, and Cutting to 4 micron in size. The pieces were placed on glass objects which had been given Meyer albumin adhesive. The next step was HE coloring which was done by immersing in Xylol $+\mathrm{Kl} 1 \%, 15$ minutes, absolute Xylol, alcohol series (absolute alcohol, 96\%, 80\%, 70\%, each for 5 minutes); staining with Haematoxylin for 10 minutes, running water for 5 minutes, $100 \mathrm{ml}$ of ethanol $70 \%+5$ drops of HCL for 10 seconds; distilling water for 5 minutes; staining with eosin, washed with distilled water and immersed in alcohol series (ethanol 705, 80\%, 96\%, and absolute alcohol), xylol 1 each for 5 minutes and xylol 2 for at least $20-30$ minutes. Then, they were covered with a cover glass and glued with entellan.

\section{Observation of SpltMNPV infection on S. litura larvae's organs}

In this study, observation data were analyzed descriptively. The pieces of $S$. litura larvae were observed under a light microscope. The observation of the infected organs was done on the anterior, middle, and posterior midguts within 0, 24, 48, and 72 hours incubations. Determining the infected organs was based upon the discovery of polyhedral inclusion bodies of SpltMNPV at each organ.

\section{Results and Discussion}

Table 1 shows the spreading of SpltMNPV in S. litura larvae's bodies which had been incubated for 0 , 24, 48, and 72 hours. In the 0-hour incubation (control), all the organs (the lumen and the midgut epithelial cells) were still free from viruses. This shows that larvae used in this incubation were uninfected with SpltMNPV. In the 24-hour incubation, the organs infected by SpltMNPV were the lumen, peritrophic membranes and midgut epithelia, fat body/fat cells (at the lumen midgut), trachea and blood vessels (only at the posterior midgut). These findings are correspond with the results of the study by Engelhard, et al. (1994) stating that after 24-hour incubation, AcMNPV (Autografa california Multiple Nucleopolyhedrosis Virus) has shown some infection signs on the epithelial midgut and tracheoblast. In this present study, there were some infection of PIB SpltMNPV on the posterior midgut of blood vessels. The findings in this study are rather different from Engelhard's study (1994), in which AcMNPV infected hemocyte in blood vessels only after 36 hours of incubation. This means that the spread of SpltMNPV is faster than the spread of AcMNPV. In the 48-hour incubation of SpltMNPV, it can be seen in the larvae's bodies that the virus had infected most of the organs (lumen, peritrophic membranes and midgut epithelia, fat body, trachea and blood vessels) except some muscle cells and the cuticles. This is in accordance with Prasad \& Yogita (2006) which confirms that SINPV attacks almost all organs (midgut, fat body, muscular layer, and basement membrane) at 48 hours post-infection. After 72-hour incubation, the worms had lost their appetite, their bodies started to change color and getting pale and slow in their movement. In this incubation, almost all organs in the midgut, anterior, middle, or posterior, were already infected, except the cuticles. In Engelhard's study (1994), all of the organs (midgut, trachea, blood vessels, muscle cells, and epidermis in cuticles) have been infected by AcMPV after 70 hours of incubation. In this study, the epidermis of the cuticles was infected, but the cuticle layers (chitin) were free from SpltMNPV infection. The cuticles were the last layers which were not infected by the virus. The virus still needs the cuticles to collect the virus from reproduction (Rohrmann, 2008).

Based on Figure 1, the spread of SpltMNPV in various organs of S. litura larvae is noticeable. The organs of S. litura infected by SpltMNPV are midgut, trachea, blood vessels, malpighian tubules, fat cells/fat body, and muscle cells. The only organ uninfected by SpltMNPV was the cuticle. The organs infected by SpltMNPV could be indicated by the SpltMNPV PIB existence in the organs (Figure 1).

The virus began to act only after being ingested through the food and getting activated in the alkaline $\mathrm{pH}$ of the midgut lumen. Midgut is the first organ targeted by the virus (Prasad \& Yogita, 2006). Inside the lumen, SpltMNPV polyhedral will be split by alkaline $\mathrm{pH}$, then the multiple nucleocapsid (MNPV) will break out and damage the peritrophic membranes by endopeptidase / metalloproteinase / enhancins enzyme. This causes much damage in the peritrofic membranes, so the peritrofic membranes are destroyed (Rohrmann, 2008). The next target cell is the midgut epithelial cells. The infection mechanism of SpltMNPV on midgut epithelial cell will begin by some multiple nucleocapsid of SpltMNPV, as to recognize the host cell membrane 
by attaching to a specific place (receptor site) and release a particular compound that can change the cell membrane, so that the cell membrane invaginate and form a tunnel. According to Rohrmann (2008), multiple nucleocapsid is attached to larva midgut cells through the interaction between vp91 (virus protein 91) and midgut cells receptor. MNPV has sensitive receptor sites so that it can bind protein and change the conformation of the compounds in the epithelial cell membrane.

Table 1 The Spread of SpltMNPV in S. litura larvae

\begin{tabular}{|c|c|c|c|c|c|c|c|c|c|c|}
\hline Hour & Histology & LM & PM & $\mathrm{ME}$ & $\mathrm{Tr}$ & BV & MT & FB & $\mathrm{CE}$ & $\mathrm{MC}$ \\
\hline \multirow{3}{*}{$\begin{array}{l}0 \mathrm{~h} \\
\text { (Control) }\end{array}$} & $\mathrm{AM}$ & - & - & - & - & - & - & - & - & - \\
\hline & MM & - & - & - & - & - & - & - & - & - \\
\hline & $\mathrm{PM}$ & - & - & - & - & - & - & - & - & - \\
\hline \multirow[t]{3}{*}{$24 \mathrm{~h}$} & $\mathrm{AM}$ & + & + & + & + & - & No & - & - & - \\
\hline & $\mathrm{MM}$ & + & + & + & + & - & - & + & - & - \\
\hline & PM & + & + & + & + & + & - & - & - & - \\
\hline \multirow[t]{3}{*}{$48 \mathrm{~h}$} & $\mathrm{AM}$ & + & + & + & + & + & No & + & - & - \\
\hline & MM & + & + & + & + & + & + & + & - & - \\
\hline & PM & + & + & + & + & + & + & + & - & + \\
\hline \multirow[t]{3}{*}{$72 \mathrm{~h}$} & $\mathrm{AM}$ & + & + & + & + & + & No & + & - & + \\
\hline & MM & + & + & + & + & + & + & + & - & + \\
\hline & PM & + & + & + & + & + & + & + & - & + \\
\hline
\end{tabular}

Note: $\mathrm{Lm}=$ Lumen, $\mathrm{PM}=$ Peritrophic Membrane, $\mathrm{ME}=$ Midgut Epithel, $\mathrm{Tr}=$ Trachea, $\mathrm{BV}=\mathrm{Blood}$ Vessels, $\mathrm{MT}=$ Malpighian Tubules, $\mathrm{FB}=$ fat body/fat cells, $\mathrm{CE}=$ Cuticle Epithelia, $\mathrm{MC}=$ Muscle Cell. $+=$ infected by virus, - = not infected by virus, $\mathrm{NO}=$ no organ, $\mathrm{AM}=$ Anterior Midgut, $\mathrm{MM}=$ Middle Midgut, $\mathrm{PM}=$ Posterior Midgut.

The next phase after the attachment of virus in a specific place on the host cell was penetration and releasing nucleocapsid in the envelope to the cytoplasm and, followed by biosynthesis of the virus components by forming virogenic stroma containing genetic materials and capsid protein (nucleocapsid). Virogenic stroma formation is regulated by a virus protein called PP31 (Rohrmann, 2008). The assembling of the virus components and the releasing of Polyhedra inclution bodies (PIBs) of SpltMNPV became the last phase. The epithelial cells were destroyed and SpltMNPV spread to the nearby organs such as trachea, blood vessels, and malpighian tubules. This is in accordance with the histo-micrograph figure obtained by Prasad \& Yogita (2006), in which SpltMNPV first enters the midgut lumen then damaging the peritrophic, epithelial tissues, fat body, blood circulatory system/hemocoel, trachea, muscle cells, and integument.

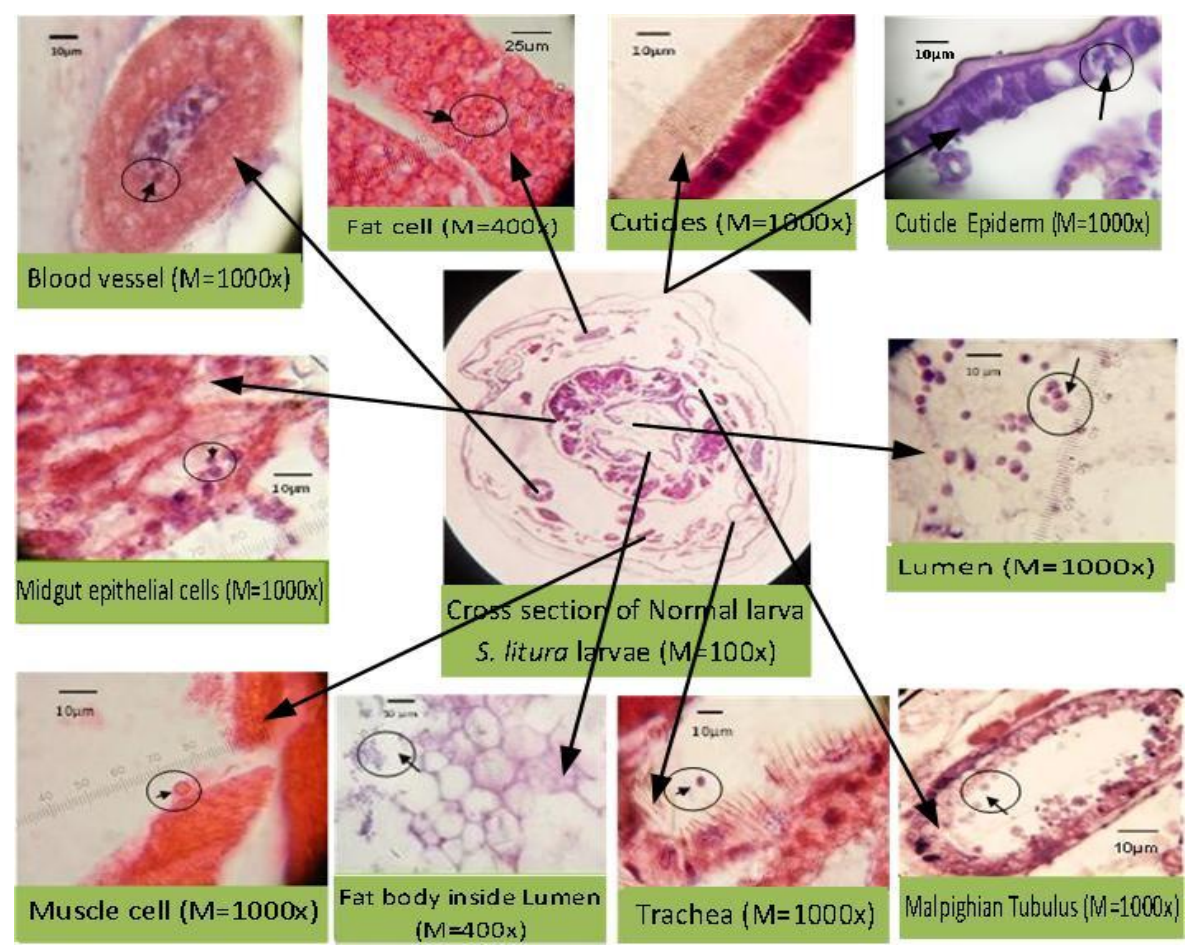

Figure 1. Organ potential to be infected by SpltMNPV at the cross section of midgut of S. Litura larvae (the short black arrow in circle points at the Polihedra inclution bodies of SpltMNPV). The organs infected by SpltMNPV included lumen, peritrophic membrane, midgut epithelial layers, trachea, blood vessels, malpigian tubules, muscle cells and adipocyte. The only organ which is not infected by SpltMNPV was the cuticle. 
Trachea is the second target of the virus infection (Engelhard, et al., 1994). The center of the trachea polyhedral inclusion bodies of SpltMNPV are already visible. According to Anonymous (2006), trachea is one of the organs in charge of supplying oxygen and excreting $\mathrm{CO}_{2}$. This organ can be infected by $B m \mathrm{NPV}$ (Bombyxmori Nuclear Polyhedrosis Virus) and is responsible for spreading BmNPV to other organs (Torquato, et al., 2006) by tracheal epidermal cell and cytoplasmic extension (Engelhard, et al., 1994). On the other hand, blood vessels in lumen also are infected by SpltMNPV, and polyhedron of SpltMNPV is shown to be oval in shape. By entering the blood vessels, it is easy for SpltMNPV to spread to the whole body. According to Keddie et al., (1989), systemic infection is mediated by free virus for some tissues, whereas infected hemocytes in blood vessels appears to spread virus to some other tissues.

In this study, malpighian tubules lumen were infected by SpltMNPV which caused the destruction of the malpighian tubules which caused the metabolism waste not be excreted from the $S$. litura larvae's bodies. This could cause poisoning in the $S$. litura larvae's bodies. The skin in insects comprises of cuticles which are composed of fibrils and chitin planted in the protein matrix. Cuticles help prevent patogens from entering the body, but if the cuticles crack due to injury or degradation, it may cause infection (Kavanagh \& Reeves, 2004). In this study the cuticles were not infected by SpltMNPV.SpltMNPV could not infect cuticles since cuticules do not have site receptor (vp91) for SpltMNPV (Rohrmann, 2008). Hence, the data showed that the S. litura larvae's muscle cells have polyhedra of SpltMNPV.

\section{Conclusion}

S. litura larvae were infected by SpltMNPV in several organs, there are lumen, peritrophic membranes, trachea, blood vessels, malpighian tubules, muscle cells and fat cells. The only organ uninfected by the virus was the cuticle.

\section{Acknowledgements}

Thanks are addressed to Directorate General of higher education, Ministry of Education and Culture, Republic of Indonesia for funding this study through a doctoral scholarship.

\section{References}

[1]. Adisarwanto, T. and Rini Widianto, 1999. Improvement of soybean crops in wetland, dry and lowtide. Jakarta: Penebar Swadaya. pp. 4-10 (in Indonesia)

[2]. Anonimous, 2006. Invertebrate Anatomy Online. Calpodesethlius Larva ${ }^{\oplus}$ Greater Canna Leafroller Richard Fox. Lander University. http://lanwebs.lander.edu/faculty/rsfox/ invertebrates/calpodes.html

[3]. Arifin, M. 1994. Utilization of SINPV as biological control agents for army worm in soybean. Meeting of Utilization biological Agency and vegetable insecticide as a means of pests Population Control. Direktorat Bina Perlindungan Tanaman. Pandaan, JawaTimur, 22-24 November 1994. pp. 10 (in Indonesia)

[4]. Asri, M.T., N. Ducha, and Dian P. 2006. An attempt to multiply SpltMNPV through in vitro as bio-insecticide using insect's cell culture techniques. Research report of Competitive Grants. State University of Surabaya.p.52-55(in Indonesia)

[5]. Asri, M.T and Isnawati, 2005. Effectiveness and characterization SpltMNPV cut off genetic material. Research Report of Young Lecturer. State University of Surabaya. pp. 41 (in Indonesia)

[6]. Engelhard, E.K., L.N.W. Kam-Morgan., J.O. Washburn, and L.E. Volkman. 1994. The insect tracheal system. A conduit for the systemic spread of Autographa california M nuclear polyhedrosis virus. Proc. Natl. Acad. USA. 91:3224-3227

[7]. Kaddie, B.A. Aponte, G.W. and Volkman, L.E. 1989.The pathway of infection of Autographa california nuclear polyhedrois virus in an insect host. Science. 243:1728-1730

[8]. Kartohardjono and Arifin, 2000.Army worm species and their natural enemies on soybean. Dalam E. Soenarjo, S. Sosromarsono, S. Wardojol. Prasadja (eds). Symposium proceeding the biodiversity of arthropods. Cipayung. pp: 371-376. (in Indonesia)

[9]. Kavanagh Kevin and Emer P. Reever. 2004 . Exploiting the potential of insect for in vivo pathogenicity of microbial pathogen.FEMS Microbiology Reviews .pp.101-112.

[10]. Marwoto and Suharsono. 2008. Strategy and component of control technology for army worm (Spodopteralitura Fabricius) in soybean plants. Jurnal Litbang Pertanian. 27(4): 131-136.

[11]. Prasad Arti and Yogita Wardhwani. 2006. Pathogenic virus and insect tissues: an effective way of pest control. Current Science. 91 (6): $803-807$

[12]. Rohrmann, G. 2008. Baculovirus Molecular Biology. Chapter 3.The baculovirus replication cycle: effects on cells and insects. Department of Microbiology, Oregon State University, Corvallis. pp.33-43

[13]. Thamrin, M., Isnawati and Djoko Budiono, 2012.Mechanism of infection Spodoptera litura multiple nucleopolyhedrosis virus (SpltMNPV) on midgut epithelial cell army worm (Spodoptera litura).Research Report of 2nd year fundamental. State University of Surabaya pp.23-25. (in Indonesia)

[14]. Torquato, E.F.B., Marcilio H. De Miranda Nito., and Rose M.C. Brancalhao, 2006. Systematic, Morphology and Physiology. Nucleo polyhedrovirus Infected Central Nervous System Cells of Bombyxmori (Lepidoptera: Bombycidae) Neotropical Entomology 32(1): 070-07

[15]. Wahyuni, E. 2002. Molecular analysis of Spodopteralitura Multiple Nucleopolyhedrosis virus (SpltMNPV) from different regions of Indonesia. Yogyakarta: Gadjah Mada University. p. 116 